\title{
9
}

\section{RUSSIA'S FIGHT AGAINST COVID-19}

\section{Dealing with a global threat under crisis and stagnation}

\author{
Viacheslav Seliverstov, Ivan Leksin, \\ Nataliya Kravchenko, Vladimir Klistorin \\ and Almira Yusupova
}

\subsection{Introduction}

The Russian Federation, covering 17.1 million $\mathrm{km}^{2}$, is geographically the largest country in the world and, with its 146.7 million inhabitants, the ninth largest in population. It is a state with medium levels of urbanisation - in terms of urban population ( 74.4 per cent), it ranks 77 th out of 218 countries - and it is sixth in a list of states by gross domestic product (GDP) based on purchasing-power parity.

Under the Constitution, the Russian Federation is a federal state made up of a complex system of 85 constituent units: republics, krais, oblasts, cities of federal significance, autonomous okrugs, and an autonomous oblast. Three federal cities Moscow, St. Petersburg, and Sevastopol - have the status of a constituent unit, with their management systems and budgets consequently independent of the region where they are located; for example, the city of Moscow is in Moscow Oblast.

Since Russia's territory is so vast, it is divided into eight federal districts, each combining constituent units in a macro-region, namely the Central, Northwestern, Southern, North Caucasian, Volga, Urals, Siberian, and Far Eastern districts. They are not official administrative or territorial units but have authorised envoys who pursue the President's policies within the boundaries of their federal districts, as well as control and coordinate the work of the existing local bodies of federal executive power at the district level.

When Russia's first Covid-19 cases were reported on 31 January 2020, a number of economic, political, and social factors combined with one another to create a highly adverse background for efforts to combat the pandemic. First, the economy was in crisis: in the preceding seven years (2013-2019), economic stagnation had set in, with GDP per capita increasing by only 3 per cent (Aganbegyan 2020). Western sanctions, imposed on Russia in 2014 after the Crimea became 
part of it, affected a few large Russian companies, among others, as well as the economy as a whole. Moreover, world oil prices dropped by half.

Secondly, the poor quality of public administration at the national and sub-federal level is compounded by a fairly high prevalence of corruption; within this context, constituent entities have been burdened heavily by social and economic inequalities (including in regard to their medical services). Thirdly, Russia has one of the longest land borders with China, the country where the virus originated.

Some favourable factors and conditions were nevertheless present. First, Russia has large gold and forex reserves that were accumulated in the past, in addition to a massive sovereign wealth fund (called the National Wealth Fund). Secondly, its enormous territory, combined with low population mobility, created natural barriers to the spread of the coronavirus. Thirdly, though much of it has been laid to waste, the system of public health care inherited from the Soviet era remains adequately functional.

The situation was further complicated by the political characteristics of contemporary Russia. Most notably, the state administration system is overcentralised, with the presidency playing a dominant role in it. The top-down command structure (consisting in what is known as 'the President's vertical power') was backed by presidential plenipotentiaries and their staff in eight federal districts established in 2002.

Furthermore, there is weak political competition. The ruling party, United Russia, dominates legislative and executive bodies at the federal and sub-federal levels: only 7 out of 85 governors represent opposition parties; two governors were elected as independent candidates; and another 20 were formally nonpartisan but in actuality nominated or supported by the ruling party. Overall, United Russia wields power over 90 per cent of Russian governors.

To these considerations, one may add that, viewed geopolitically from the perspective of identifying sources of global-threat proliferation, Russia is an asymmetric federation with an excessively centralised and low-quality state administration system. Such conditions led to apprehensions that the Covid-19 pandemic would spread rapidly and uncontrollably in Russia, but, fortunately, these fears proved unjustified.

The country's first two Covid-19 cases, involving Chinese citizens visiting Russia, were recorded in Siberia on 31 January 2020. The first case in Moscow was identified on $2 \mathrm{March}$, which was a month later than happened in most countries in Europe and attributable to the quick closure of the border with China (on 31 January 2020) and then those with other countries. This bought some time in which to put in place the minimum necessary conditions for receiving patients in Moscow and the regions.

In the first wave of the pandemic, infections peaked on 11 May (11,600 people per day), and fatalities on 29 May 2020 (213 people per day). Over the summer (until the end of August), the infection rate decreased, then started to grow slowly. The second wave emerged in early October, with peak daily infection 
and mortality rates exceeding those of May. By 31 October, Russia was seeing 18,140 new cases per day; it had also recorded a total of 1.618 million cases, 1.215 million recoveries (i.e., 75 per cent of all cases), and 27,990 deaths.

Russia's constituent entities varied significantly in infection rates. The areas most affected by Covid-19 were those with high population density and mobility, namely the largest cities, North Caucasus, and regions in the north where people work primarily on a rotational basis.

This section has outlined some of Russia's distinctive features as a pandemic site and provided an overview of how Covid-19 spread through its territory in the course of 2020. The sections that follow examine how it responded to the crisis as a federation and what key actions it took in terms of its constitutional and legislative framework and within the context of its intergovernmental relations (IGR) between the centre and the regions.

\subsection{The federal constitutional and legislative framework}

The Constitution of the Russian Federation of 1993, as amended in 2020 (RF Constitution), contains general provisions that are applicable to a wide variety of disaster situations. These provisions include ones that set out the federal structure, declare the autonomy of local governments, specify the jurisdictions of government orders, and define the powers of the federal president and federal government.

In terms of articles 71 and 72 of the RF Constitution, governmental powers are divided into two categories: those under federal jurisdiction and those under the 'joint jurisdiction' of the federal and 85 regional governments. Many of the constitutional formulas in the respective lists are equivocal and thus open to varying interpretations, making the distribution of powers quite flexible and leaving a small degree of latitude for exclusive regional legislation. As far as pandemics are concerned, two jurisdictional areas are relevant, disaster management and health care, both of which used to be regarded as matters of 'joint jurisdiction'.

The joint jurisdiction of the Russian Federation and its constituent units is not 'joint' in the proper sense. Some intergovernmental coordination is provided for when it comes to implementing federal statutes on matters within joint jurisdiction, but the RF Constitution does not put federal and regional law-making at a par with each other or set any limits on federal law-making within the area of joint jurisdiction. In fact, this area is concurrent, with the federal legislator enjoying overwhelming predominance (Leksin and Seliverstov 2017). It was by means of federal statutes that, within less than two decades after the adoption of the 1993 Constitution, Russia evolved from a loose, semi-confederate arrangement into a highly centralised federal state (Leksin 2016).

With regard to local government, article 12 of the RF Constitution asserts that local self-government constitutes a separate form of governance; however, local governments' powers do not cover an exclusive sphere of jurisdiction that could be separated from the powers mentioned in articles 71,72 , and 73 of the 
RF Constitution. The constitutional assertion that municipalities enjoy self-government means no more than that they execute federal and regional laws.

Detailed statutory provisions dealing with the allocation of powers are found in several federal statutes. According to the statutes regarding a pandemic, the federal and regional governments are both responsible for issues that include protecting human rights in health care, organising medical care and licensing certain types of activities in health care, and facilitating medical treatment by medical institutions. The federal government deals mostly with policy-making, law-making, administrative regulation, and supervision, while the regional governments deal mostly with the practical issues of health protection; local governments fulfil auxiliary functions. The single-tier and upper-tier municipalities participate in health protection activities in several ways: they are responsible for, among other things, creating the conditions for providing medical care to the population, preventing diseases, ensuring the provision of medical care in municipal health-care institutions, warning the population about epidemic threats, raising awareness about healthy lifestyles, and promoting blood donation.

The jurisdiction over disaster management is more decentralised. Every level of government is responsible for dealing with emergencies, depending on the scale of the latter. As such, federal, regional, and local governments are entitled to declare a 'regime of emergency situation' or a 'state of heightened preparedness' in order to mobilise the necessities for (1) protecting the population; (2) evacuations and emergency rescues; (3) keeping stocks of material, including food and medical supplies, for purposes of civil defence; and (4) informing the population in the emergency zone about the status of the situation and the measures taken in response to it. However, only federal and regional governments are entitled to make laws on population-protection measures and to maintain public order during emergencies.

Because disaster management falls within 'joint jurisdiction', federal statutes play the leading role. Federal legislation since the 1990 s used to distinguish between three legal regimes related to emergencies. The first was called the 'regime of emergency state'. According to the 1993 RF Constitution, the President can introduce this regime in the entirety of the Russian Federation or in certain parts only. Having introduced it, he immediately has to inform the chambers of the Federal Assembly (the State Duma and the Federation Council). The Federation Council is entitled to confirm the presidential decree. The RF Constitution does not go into detail about the nature of this regime but refers instead to a special statute (a federal constitutional law) that should establish the rules for it. This special statute was enacted finally in 2001 but has never been used. States of emergency were declared several times between 1992 and 1995, though not on epidemiological grounds.

Along with the 'regime of emergency state', two other legal regimes applicable in the case of a national disaster are provided for in the federal law, On the Protection of Population and Territory against Natural and Technogenic Emergency Situations (1994). These are the 'regime of emergency situation' and 
a 'state of heightened preparedness'. While they are little different in content, the first refers to the period after the emergency has occurred, whereas the second can be introduced when there is the threat of an emergency.

All three regimes can be introduced to address natural or man-made emergencies, including epidemics. However, the primary objectives of the 'regime of emergency state' are restoring law and order and ensuring safety during armed rebellion; attempts of violent overthrow of the regime; terrorist attacks; and national, confessional, and regional armed conflicts; the two other regimes are focused on disaster management.

\subsection{Preparedness for a national disaster: The institutional framework}

The Russian Federation has a huge network of institutions dealing with disaster management. The most relevant of them are as follows:

- The Federation Ministry of Health Care, and, under it, the Federal Health Care Surveillance Service with its regional departments.

- The Federal Service for Surveillance on Consumer Rights Protection and Human Wellbeing and its regional subdivisions. This institution played a leading role in administering the 'state of heightened preparedness' during the pandemic in 2020, even though it had been regarded previously as of minor importance.

- The Federation Ministry of Emergency Situations and its regional departments. These used to be the leading problem-solvers during natural and mademade disasters but played only a supporting role in the response to Covid-19.

- Regional ministries and agencies performing administrative and supervisory functions in the areas of health care and disaster management.

In the past decades, Russia's system for managing disasters has undergone changes in regard to the executive branch. With natural disasters having become more common due to climate change, the Federal Ministry of Emergency Situations, along with similar departments of the regional governments and local administrations, had to be enhanced significantly. The federal executive bodies governing health-care issues (and similar departments of the regional governments), as well the ones tasked with supervision of hospitals and other medical institutions, evolved mainly in terms of their functions, which were altered in the course of updates to legislation and health-care standards.

Subordination between the federal and regional ministries, agencies, and the like does not exist in a formal sense. However, federal ministries issue standards and other regulations that are to be followed by regional hospitals and organisations for which regional governments are responsible. Thus, indirectly, regional executives are influenced significantly by the Federal Ministry of Health Care and similar bodies when it comes to preparedness for disasters. 


\subsection{Rolling out measures to contain the pandemic}

The unprecedented crisis caused by the pandemic changed the way in which state power and governance in Russia are organised, primarily by affecting relationships and functions among the central, regional, and local levels of the federal structure. Three stages may be identified.

In the first (January to February 2020), federal authorities took preventative measures to contain outbreaks (for instance, closure of borders) and make medical preparations. In the second stage (March to early April 2020), they continued combating the pandemic, but one region exercised its own judgment, Moscow (as Moscow metropolis is a separate constituent unit in the federation). In the third (from April 2020 onwards), the foci of decision-making moved to the regions. Simultaneously, federal agencies carried out large-scale hospital construction and, among other things, secured equipment and specialist supplies.

Notably, from the outset, Russia's efforts to combat the pandemic did not involve interparty conflict. The entire parliamentary opposition - that is, the three parties called the 'systemic opposition' - supported the President and the government in the measures they took. The non-systemic opposition - in other words, the parties which are excluded from the political system and absent in state government agencies and which are strongly opposed to the ruling party and status quo - did not consider it appropriate either to capitalise on the hardship the pandemic brought to the country. As mentioned, the ruling party's rigid discipline, adhered to by most of the governors, reinforced its dominance.

\subsubsection{Taking the initiative}

Before the first cases of Covid-19 were recorded on 31 January 2020, the federal government, in response to events in China, moved into action. On 27 January an operational headquarter ('task force') was established for the prevention of Covid-19, with Deputy Prime Minister Tatiana Golikova appointed as its chief. Later, similar 'task forces' appeared under the governments in all Russian regions and large cities. As measures to prevent the coronavirus from entering Russia, borders with China were closed on 31 January and later with other countries, while rail traffic was suspended and most flights cancelled.

After Moscow reported its first case of infection on 2 March 2020, the city government imposed lockdown measures on 5 March. In a national televised address on the same day, President Vladimir Putin announced a stay-at-home period (called 'non-working days' in Russia) from 30 March to 3 April 2020. Then, in a national address on 2 April, the President extended this until 30 April. On 30 March, Prime Minister Mikhail Mishustin asked regional authorities to consider the measures taken in Moscow and explore whether they could follow the capital's example. As a result, 26 regions had declared a lockdown (the 'self-isolation regime') by 31 March. On 8 April, President Putin instructed regional leaders to take measures independently from Moscow in line with the epidemiological situation. 
Although federalism in Russia has tended towards centralisation since the early 2000s (Leksin 2008; Seliverstov 2015), the pandemic managed to shake the division of powers between the centre and the regions to a certain extent. From April 2020, restrictions and other measures aimed at fighting the pandemic, ensuring the health of the population, and supporting local economies were entrusted fully and personally to the governors of the regions (Presidential Decree No. 239 of 2 April 2020). At the same time, President Putin maintained strict control over the regional authorities and what they did; presidential plenipotentiary representatives in eight federal districts served this purpose. The federal government also retained management over the powers transferred to constituent units by, for example, issuing standard guidelines for regional governments and setting criteria for lifting restrictions and switching to softer measures.

The role and importance of several federal structures changed with the roll-out of pandemic response measures. For instance, the Federal Service for Surveillance on Consumer Rights Protection and Human Wellbeing (Rospotrebnadzor) and its regional departments came to the fore. From March 2020, this authority collected and processed all operational information on the spread of the virus, as well as drafted decisions and recommendations for other federal executive bodies.

In the complex system of measures to manage the pandemic nationwide and locally, we should note the President's role. Putin was well aware that the pre-existing crisis in Russia's economy would be compounded by negative public reaction to the pandemic's consequences and affect his popularity. Therefore, especially in the first stages, he took the initiative, showed himself demonstrably in control of the situation, and interacted continually with federal and regional authorities. As part of this, he delivered numerous televised addresses, and between April and May 2020, held almost weekly live-broadcast videoconferences with governors. Clearly, the President's actions were taken with an eye to the anticipated summer constitutional amendment referendum, a matter that received his special attention. ${ }^{1}$

\subsubsection{Federal action}

The actions taken by federal authorities fall into three main categories: situational monitoring and raising public awareness, coordinating devolved powers, and undertaking planning and economic support.

\subsubsection{Monitoring and raising public awareness}

In the face of extreme uncertainty, a panic epidemic can be as harmful as a viral epidemic: a rising flow of spontaneous information about the spread of disease increases societal tension and frustration. Accordingly, the State Centre for Information of Citizens about the Coronavirus, established in mid-March 2020 , created an official public website covering these issues to advance public education. 


\subsubsection{Coordination and devolving powers}

Between 2 April and 30 May 2020, President Putin issued three decrees granting extended powers to the top officials in the constituent units. These legal instruments enabled them to take a range of response measures to Covid-19 depending on the particular circumstances within their jurisdictions.

The Amendment Law No. 1-FKZ of 14 March 2020 introduced an additional matter under exclusive federal jurisdiction, namely, 'setting the common legal basis for the healthcare system'. At the same time, the matter of joint jurisdiction, referred to in article 72 of the RF Constitution as 'coordination of the healthcare issues', was supplemented by provisions, inter alia, for widely available and high-quality medical care and the promotion of healthy living.

Several structures were established at the federal level for developing and implementing measures to combat Covid-19 and support the economy: operational headquarters for cooperation between the relevant executive authorities (which included the heads of federal ministries); a government commission (comprising heads of federal ministries and two heads of constituent units) to ensure sustainable economic development; a government coordination council (comprising heads of federal ministries and two heads of constituent units) to control the incidence of coronavirus infection; and a state council working group (consisting of federal and regional heads) to counter the spread of the virus.

There was also coordination of procedures for lifting Russia's nationwide restrictions after a first wave of coronavirus infections abated. The date 11 May 2020 marked the end of the 'non-working days' that had been in effect since 28 March. The federal government announced a three-stage plan for easing restrictions, one in which governors were given the right to decide when and how to lift them, albeit subject to the mandatory requirement that they comply with federal health regulations. Phase 1 allowed walks and open-air exercise, and small shops and service providers were permitted to reopen. Phase 2 permitted the opening of schools, large shops, and service companies, while Phase 3 extended this to parks, hotels, restaurants, and all shops. The criteria for easing restrictions in certain regions included infection rates, the availability of hospital beds, and testing for Covid-19.

\subsubsection{Planning and economic support}

The most important outcomes of the governmental commissions and coordinating bodies mentioned above were the Plan of Priority Measures (Actions), approved by the federal government on 17 March 2020, for ensuring sustainable economic development in the face of a worsening situation due to the spread of infections, followed by a plan, approved on 20 April, to address the pandemic's economic consequences. Within a few weeks in April and May, the government announced three packages to combat the pandemic and support the economy and population. 
An important task for the federal authorities during the first months was to rectify shortages of personal protective gear, medicine, and equipment. Between March and April 2020, the number of tests for the virus increased ninefold; by mid-October, 200 test systems were being used to diagnose for Covid-19, of which more than 80 were of domestic origin. This fact places Russia among the world leaders in coronavirus test coverage (as of 31 October 2020, 60.4 million tests had been performed). In addition, by that date the number of hospital beds available for infected patients had quadrupled to 200,000.

In this regard, the Ministry of Defence made a significant contribution. Within a short period, it built 20 inpatient hospitals (on average, two months per hospital) in various regions of the country. Field hospitals were also set up in particularly disadvantaged constituent units, such as the Republic of Dagestan and the Transbaikal Region, while military personnel provided health treatment in some of the most affected areas.

The first package of federal economic support included credit holidays for smalland medium-sized businesses and certain categories of citizens, financial support for affected industries, and a preferential loan programme for paying wages. The most significant measure was a reduction - from 30 per cent to 15 per cent - in social insurance payment rates for small and medium-sized businesses. The second package, to the value of about 1 per cent of GDP, sought to assist strategically important companies, support regional budgets, and provide increased pay for health workers.

Both of the packages were criticised for being insufficient, focused on businesses rather than citizens, and lacking in cash transfers to beneficiaries. The third package, however, was larger, amounting to about RUB 800-900 billion, and provided for direct payments for families with children, for those recently unemployed due to business interruption, and for other socially vulnerable groups. Nevertheless, experts (Aganbegyan 2020) deemed these measures as inadequate, maintaining that the country's gold and forex reserves, along with the Russian National Wealth Fund, made it possible to (at least) double support for people and businesses affected by the pandemic.

On 23 September 2020, the federal government approved the National Action Plan to ensure the recovery of employment and income, economic growth, and long-term structural reform to the economy. Although morbidity had increased notably by then, the document did not mention this second wave of infection but spoke rather of restoring employment, supporting entrepreneurship, launching a new investment cycle, and improving the business climate. Other topics dealt with accelerating technological development, boosting exports, and encouraging import substitution.

\subsubsection{Regional action}

The decentralisation of decision-making during the pandemic highlighted how vastly different Russian regions are in terms of socio-economic development and the availability of tangible and intangible resources. Experts emphasise that 
this often happens when, in the face of unmanageable crises like Covid-19, the federal centre seeks to shift responsibility for tough or unpopular measures to regional authorities (Smyth et al. 2020); as a result, the task, say, of making trade-offs between the need to preserve citizens' health, on the one hand, and to sustain economic activity, on the other, is ultimately transferred to regional governments. Thus, it was that in the Russian Federation, it was the governors, not the President, who closed down business operations and imposed restrictions on people's movement.

During the pandemic, the jurisdiction of the federation's constituent units was increased. In terms of Federal Law No. 98-FZ (1 April 2020), the regional governments received one - though highly significant - power, namely, the power to determine the rules of conduct during the 'regime of emergency situation' and the 'state of heightened preparedness', rules that were binding on citizens and organisations. Regional legislatures and executives made avid use of this innovation, imposing limitations on rights that hitherto had been possible only under either martial law or a federal state of emergency.

\subsubsection{Pandemic control measures}

The regions actively engaged in the fight against the pandemic. In March 2020 alone, the heads of regions issued more than a thousand regulations that imposed restrictions of varying degrees of severity. These were based on Federal Law No. 68-FZ (21 December 1994) On Protection of Civilians and Territories from Emergencies Caused by Natural and Man-made Disasters, on Federal Law No. 52-FZ (30 March 1999) On Sanitary and Epidemiological Well-being of the Population, and on regional laws for protecting civilians and territory during emergencies.

The speed with which regions managed to respond to the coronavirus depended more on central government directives than on the epidemiological situation in any given region. The Russian Federation itself did not declare a national state of emergency. Instead, some of the first restrictions were introduced by the Moscow government on 5 March 2020. While the Republic of Buryatia was the only constituent unit to declare a state of emergency - which it did on 18 March, a point when no cases of Covid-19 had been recorded there yet - the majority of the regions (a total of 45 constituent units) imposed a 'state of heightened preparedness', with the rest operating under variants of the 'restriction state', which is less than 'a state of heightened preparedness' to enable them to respond promptly to outbreaks (Garant 2020).

Research by the St. Petersburg Policy Foundation divided the constituent units into three groups according to the severity of their restrictions (the so-called viral sovereignty index) (St. Petersburg Policy Foundation 2020). The toughest ones were adopted in 14 regions; 33 units were classified as average; and another 36 introduced relatively soft restrictions. Kalabikhina and Panin (2020) also identified three levels of lockdown measures (strict, medium, and low). The tighter the restrictions, the greater the possible economic losses and social tensions. 
Moscow adopted the strictest measures, among which was QR (quick response) code contact tracing to control citizens' mobility. Some constituent units also introduced so-called digital passes but later abandoned this practice. A few regions kept a tight hold on visitors from Moscow, St. Petersburg, and other major cities. Many tried to introduce strict traffic control (Nizhny Novgorod), while the Chechen Republic and the Republic of Crimea first closed entry completely but then retracted the measure. When Ramzan Kadyrov, the head of the Chechen Republic, closed the region's borders entirely, his actions drew harsh criticism from Prime Minister Mikhail Mishustin, who warned the Chechen leader not to confuse the regional with the federal scope of authority.

Although Putin announced 12 May 2020 as the end of 'non-working days', the decision as to when to start lifting the specific Covid-19 restrictions was up to the governors who imposed them. Russian regions began easing quarantine restrictions starting from May 2020, almost immediately after the number of cases had peaked. In Moscow, most restrictions were significantly eased or lifted as early as June, but in other regions, they remained in place for longer and fell markedly by 1 September.

Regional government measures to combat the pandemic led not only to a gradual reduction in the number of people falling ill, but also to sharp drops in economic demand and household income, the curtailment of a large part of the service sector, and the virtual collapse of several industries, for example, tourism and the hotel and restaurant trade. Governmental restrictions were particularly devastating for small and medium-sized enterprises (SMEs).

\subsubsection{Support for regions}

At the end of April 2020, about a month after the restrictions were introduced, the federal government developed the Corona Crisis Action Plan, in terms of which all 85 constituent units adopted economic measures to stimulate local business: 84 regions had non-tax-support measures (e.g., subsidies and reductions in rental rates), while 80 also had tax-support measures (such as tax deferrals and abatements). It is estimated that, all in all, the regions deployed 839 economic measures, 45 per cent of which were tax-related and 55 per cent, non-tax-related. The most common ones were tax incentives, deferred rent for small businesses and companies from affected sectors, and subsidies to SMEs (Mavrina 2020).

According to rankings by the National Rating Agency (2020), Moscow, the Republics of Buryatia and Crimea, Perm Krai, Chukotka Autonomous Okrug, Tula, Irkutsk, and Chelyabinsk Oblasts took the most measures to support businesses affected by the pandemic. Support from local authorities may have buffered regional economic decline, but in the pandemic situation, it simply harmed many regional budgets. Regional economies that were the most affected by the restrictions suffered primarily due to regionally specific circumstances rather than the pandemic itself. Therefore, the search for a balance between economic well-being and health in these regions shifted, quite predictably, towards 
economic well-being. As survey data show, support measures were not available to everyone who needed them (Chamber of Commerce and Industry of the Russian Federation 2020).

Our analysis suggests that the downturn in economic activity was likely to have a negative impact on regional development and increase regional disparities in terms both of economic indicators and of social well-being. Experts have underlined that transferring authority and responsibility for the fight against Covid-19 to regions where resources are scarce would, first of all, increase regional expenses: indeed, it is estimated that budget expenditure increased by 30 per cent over six months and that more than half of the regions experienced increased budget deficit (Komin and Poltoratskaya 2020; Trunova and Zemlyanski 2020).

The arrangement in turn would have made disadvantaged regions lacking in resources of their own even more dependent on the centre and its financial support. Given that the capacity to support people and businesses depends on regional economic and social development (primarily in the health-care system), more advanced and wealthier regions would be able to fight the pandemic more effectively than poorer ones, leading to greater inequality. Possible long-term negative consequences include deferred problems in the economy (including those resulting from reduced private sector investment) and increased social tensions.

\subsubsection{Federal-regional dynamics}

The need for prompt solutions and the high level of diversity in living and working conditions across the country inevitably led to decision-making on specific measures being delegated to the regions. This process, as noted, exacerbated existing problems and created new ones.

During the pandemic, the centre exercised supervision over the situation in the regions, with the President or the federal government intervening in certain cases to enable regions to carry out their devolved functions. Due to the existence of multiple channels for transmitting information requiring action and difficulties in coordinating individual agencies, sometimes only the centre's direct intervention could clear the red tape.

After the Federal Service for Surveillance on Consumer Rights Protection and Human Wellbeing criticised them for the inadequacy of their measures to combat Covid-19, several regional heads (those of Kamchatka Krai, Arkhangelsk Oblast, and the Komi Republic) handed in resignation letters to the RF President (RBK Information Agency News 2020). The Governor of Khabarovsk Krai was dismissed by the President for loss of trust and confidence (TASS Information Agency News 2020).

In a few cases involving abnormal outbreaks and inadequate health-care systems in constituent units, the federal government provided improved capacity at federal medical centres, ambulance services from neighbouring regions, and hospital construction by the defence ministry. 
The Covid-19 crisis again illustrated a fundamental problem with Russian federalism: the gap between how much responsibility regional (and municipal) authorities have in comparison to the resources and powers available to them and their capacity to fulfil their responsibilities.

\subsubsection{Self-government in cities and municipalities}

One well-known feature of Russian federalism is the relatively weak role that cities and municipalities play in the administration (Chikhladze et al. 2020). Their subordinate place in intergovernmental and fiscal relations is due largely to the limited possibilities for drawing up local budgets. In the fight against the coronavirus, this all became clearly apparent when major decisions and concrete measures were taken at the national and regional levels, while cities and municipalities worked with whatever funds they had. While there is no doubt that city authorities did not take a passive stance in combating Covid-19, their actions were limited by their powers, on the one hand, and, on the other, their physical and financial resources.

For example, the mayor's office in Novosibirsk (the third-most populous city in Russia) monitored the availability of drugs in pharmacies across the city and, in case of shortages, negotiated with manufacturers and suppliers. Similarly, a shortage of personal protective equipment (PPE) was eliminated swiftly with its help. Considerable effort was also put into supporting municipal hospitals and medical institutions. As a second wave of infection started to emerge, the city authorities began well in advance to retool individual hospitals, health centres, and social assistance centres in their jurisdiction for treating coronavirus patients.

Moscow City, as a unit of the federation, made the most effective and innovative governance decisions. Among other things, the local administration used CCTV and facial recognition to control patient mobility; devised special schedules for Muscovites to go out and get groceries during the first wave of infection; used QR code contact tracing; and deployed systems to control travel using personal transport. The city authorities also paid great attention to improving remote learning for schoolchildren and students. Crucially, the mayor, Sergey Sobyanin, was personally and constantly engaged in resolving issues and in direct contact with the population.

The effectiveness of Moscow's management of the pandemic meant that the rest of the country could avoid economic collapse and social instability. Moscow may yet become a kind of laboratory for testing managerial solutions within the digital economy.

\subsubsection{Intergovernmental relations}

In Russia, intergovernmental relations (IGR) are facilitated via various institutions, officials, and procedures (Leksin 2018). First of all, the President and the two chambers of the Federal Assembly, namely, the State Duma and Federation 
Council, are important instruments of IGR. Under the RF Constitution, the President ensures coordinated functioning of the country's governing bodies. In fact, he is the key IGR instrument, albeit influencing regional governors mainly through informal meetings and consultations. The State Duma also enables informal IGR, but it interacts directly and formally with regional legislatures and executives, which are entitled to make submissions on federal bills on matters of joint jurisdiction. The Federation Council's relations with regional governments are the closest of all, given that every regional legislature and executive has a representative in the Federation Council.

Furthermore, specialised institutions exist for enhancing the interaction between orders of government. These are advisory bodies, including the RF State Council, the Council of Legislators under the Federal Assembly's chambers, and the councils under plenipotentiary representatives of the President in the federal districts. Such institutions were not explicitly designed to deal with disasters; they were designed to enable discussion and cooperation, not to make orders or execute them. However, all of these structures were involved in disaster management during the pandemic. For instance, a specialised working group on pandemic issues operated within the RF State Council.

The intergovernmental structures designed to face a wide variety of challenges, including national disasters, are primarily the above-mentioned Federation Council, the State Council, and the councils under the President's plenipotentiary representatives in the federal districts. The State Council of the Russian Federation is an advisory body chaired by the President and consisting of the leaders of all the constituent units, as well as of a number of federal officials. Similar bodies exist under the plenipotentiary representatives of the President in the eight federal districts.

The IGR structures of a technical nature are provided for in the federal law, On the Protection of Population and Territory against Natural and Technogenic Emergency Situations (1994). This statute entrusts coordination of emergency prevention and response activities to a system of specialised bodies. The system consists of commissions that can comprise officials representing two orders of government, the ministries and other governmental structures designed to deal with emergencies, as well as the national control centre at the federal level and crisis management centres at the interregional and regional levels.

In addition, during the pandemic, governments at all levels established bodies designated as 'task forces'. At the federal level, separate ministries and agencies created their bodies of this type. According to the regulations establishing these bodies, they perform coordinating and advisory functions. However, their recommendations are generally taken as mandatory guidelines for governmental bodies and legal entities. These institutions also provide for intergovernmental coordination, given that their informal nature permits them to constitute an organic hierarchy. At a minimum, 'task forces' at the lower levels convey information upwards and follow directions from above. 
Apart from these institutions, other informal means of enhancing intergovernmental cooperation are relatively common. These include councils and meetings of officials responsible for various health-care and disaster management issues.

Horizontal cooperation among regional and local governments did not burgeon during the pandemic, seeing as every government was responsible for taking measures within its own territory. However, coordination and sharing best practices were common occurrences. For one thing, because Moscow was the first to experience mass contagion, most regional governments followed the broad pattern laid out in the policies it adopted; for another, adjacent regions occasionally employed coordinated lockdown measures. For instance, during the most restrictive period, driving in vehicles without having a digital pass was banned in many regions - because each region issued its own passes, it was inconvenient to travel through several regions using this kind of system. However, the e-government platforms of Moscow City and Moscow Oblast (Moscow province) issued passes valid in both regions.

The pandemic also led to instances of interregional discord, especially during the first months. For instance, various regional governments arbitrarily decided to impose a 14-day quarantine on visitors from regions with high infection rates (particularly Moscow), with some even closing their borders to entry. The federal government responded with verbal criticism, but no punitive measures were exacted, as the disputes were settled informally.

It should be noted that many problematic issues in IGR during the pandemic were resolved through hands-on management (common in Russia). Several governors sought a personal meeting with the President, where they asked for special federal support due to crisis in their regions. Such informal arrangements, for instance, ensured the construction of field hospitals for Covid-19 in Dagestan and inpatient hospitals in other territories.

\subsubsection{Intergovernmental fiscal relations}

At present the share of regional and local budget revenues in the consolidated budget of the Russian Federation is 34.7 per cent. Moreover, there is a significant asymmetry in the distribution of federal support - 16 regions do not receive transfers from the federal budget while in some regions the share of transfers in their budget revenues is higher than 70 per cent, for example, in the republics of the North Caucasus and the Republic of Crimea.

In the first half of 2020, the intergovernmental fiscal transfers provided to the regions amounted to RUB 1.4 trillion, which was 1.6 times higher than in the first half of 2019. However, a low level of expenditure is observed - on subsidies (29 per cent) and other transfers (30.6 per cent) on non-Covid related activities.

As of 1 July 2020, the federal government had adopted about 80 resolutions on the allocation of funds to address the following: supporting measures to ensure that the worsening situation did not impact on economic sectors and their 
development; preventing and eliminating the consequences of the pandemic; and protecting the population's health and treating the ill, along with other pandemic-related support to citizens. All this amounted to RUB 1.3 trillion. The most significant support measures were social spending on benefits to families with children under 16 years (RUB 496.5 billion) and grants to the constituent units allowing them to balance their budgets while providing medical care to Covid-19 patients (RUB 168.2 billion).

In general, the revenues of the consolidated budgets of constituent units for January-June 2020 were 2.1 per cent higher than in the corresponding period in 2019, amounting to RUB 6.3 trillion. However, the expenditure during the first half of the year increased by 18.9 per cent and amounted to RUB 6.5 trillion. Such a ratio of income to expenditure growth rates is due to the fact that during the first half of 2019, the regions' total budget resulted in a surplus of RUB 695.7 billion, while 2020 showed a deficit of RUB 213.7 billion.

The growth in expenditure was mostly covered by uncompensated receipts from the federal budget. A decrease in revenue of the consolidated budgets of constituent units was observed in 16 regions, with the largest ones in the YamalNenets Autonomous District (19.2 per cent) and Tyumen region (17.2 per cent). However, due to higher transfers, an increase in income was observed in 69 regions, with the largest ones in the Jewish Autonomous region (39.3 per cent) and the Republic of Ingushetia (35.2 per cent).

In most units of the Russian Federation, business support was provided from regional budgets regardless of the size of their own-source revenues and deficits since a basic source of resources were federal transfers and budget loans provided by the federal Ministry of Finance. Commercial loans were generally less significant for closing gaps in regional and local budgets.

The federal government allocated RUB 300 billion as transfers and grants, and it restructured budget loans for RUB 69.5 billion. Moreover, the government mitigated measures of responsibility for the fulfilment of obligations under the agreement with the regions and eased requirements for the parameters of the debt load on commercial loans. Experts estimated that the shortfall in regional budget revenues was about three times higher, and believed the support from the centre was still insufficient (St. Petersburg Policy Foundation 2020).

With more financial resources allocated to them, constituent units became accountable for their response measures to Covid-19 and the socio-economic impact of the pandemic. The federal centre also imposed stricter control on spending and policy efficiency. Based on these conditions, one can conclude that centralisation in public administration has strengthened in Russia.

\subsection{Findings and policy implications}

Several conclusions can be drawn from this case study of the Russian Federation.

First, Russia's success in pandemic response was due to the joint efforts of the central and regional authorities. These efforts were facilitated to a large extent by 
strong presidential vertical power and the ruling party's dominance over regional and municipal administrations. As a result, Russia avoided centre-region confrontation, interparty competition, tensions between national autonomies and the central government, and interreligious conflicts.

Secondly, despite the increasing centralisation of Russian federalism in recent decades, a certain balance of interests between the centre and regions was achieved during a crisis-ridden 2020. In view of Russia's vast size, the inequality among its constituent units, and the significant regional disparities it saw in the spread as well as control of the coronavirus, a decentralised approach to countering the pandemic was the only viable option.

Delegating powers to the units to combat the pandemic from April 2020 onwards generally strengthened federative principles in Russia, albeit that it did not result in new formalised structures for IGR. In some cases, interstate and inter-budgetary relations were nevertheless either inadequate or only semi-formal in nature. As such, one of the implications of the crisis the federal system faced in 2020 is that Russia should make provision for a more consolidated form of decentralisation, for stronger centre-region bonds, and better institutional support for IGR processes - all of which improved immensely during the fight against the pandemic.

Thirdly, most constituent units and urban settlements in Russia coped adequately with the pandemic at its onset, with some, such as Moscow and Novosibirsk Oblast, employing particularly innovative models of crisis management. However, when the authority to make decisions was given to the regions, they were often reluctant or unprepared to leverage their newfound powers due to poor regional governance. In several regions, the federal centre was forced to intervene in the fight against Covid-19, allocate additional resources, and impose strict control measures.

Fourth, in this regard, a lesson for the future is that there is a need to find an equilibrium and compromise between Russia's competitive federalism and the cooperative form prevalent in certain European countries. On the one hand, the fight against global threats will require, as noted, widespread solidarity based on the understanding that these are common rather than private or sectarian issues. On the other hand, the inevitable growth of the digital economy and, with it, phenomena such as telework and telemedicine, will lead to greater 'digital inequalities' among Russian regions and thus to even greater asymmetry and competition among them for qualified personnel, new technologies, personalised medicine, and more.

Special measures will hence be needed in intergovernmental and interbudgetary relations to smooth out such asymmetry in the future. Although one of the dominant features of 'wild' Russian federalism during the deep economic and political crisis of the 1990s - namely, political loyalty by regional elites in exchange for federal resources - is a thing of the past, the next goal is finally to eliminate elements of this system that make it necessary to rely on hands-on management of federative relations by the President alone. 
As 2020 showed us, the current high centralisation of executive power in Russia's federal system is likely to have reached its limit and can hardly intensify any further. The joint fight against the Covid-19 pandemic triggered decentralisation processes in relations between the Russian federal centre and regions. Moreover, we may consolidate this fairly successful experience and expand it not only to other crises but also the general development of federalism in Russia.

\section{Note}

1 The national constitutional referendum was held in Russia between 25 June and 1 July 2020. The proposed amendments included various social guarantees and human rights; changes to certain powers held by the Federal Assembly; granting the President extended authority and reducing that of the government; and judicial reforms establishing the supremacy of Russian law over international law. A major amendment concerned nullifying the number of presidential terms served, thereby allowing Vladimir Putin to remain in power after his term ends in 2024. In the referendum, 78 per cent of voters supported these amendments, with the percentage varying from 44 per cent to 98 per cent across the constituent units.

\section{References}

Aganbegyan, A. G. 2020. 'Crisis as a Window of Opportunity for Socio-economic Development', Moscow Economic Academic Forum, 14 May, https://www.ieie.su/ assets/files/news/2020/statya-aganbegyana.pdf (accessed on 11 October 2020).

Chamber of Commerce and Industry of the Russian Federation. 2020. 'Business Barometer First Stage', http://ngtpp.ru/wp-content/uploads/2020/04/Prilozhenie_ITOGI-BBS1-939160-v1.pdf (accessed on 2 October 2020).

Chikhladze, L. T., A. A. Larichev and E. N. Khazov (eds). 2020. Local Government in a Unified System of Public Administration: Vector and Consequences of the Constitutional Reform in the Russian Federation. Moscow:YUNITI-DANA.

Garant. 2020. 'Legal Information System', http://base.garant.ru/77398959/ (accessed on 8 October 2020).

Kalabikhina, I. and A. Panin. 2020. 'Spatial Choreography of the Coronavirus', Population and Economics, 4(2): 123-52.

Komin, M. and V. Poltoratskaya. 2020. 'Responsibility Instead of Rights: Did the Pandemic Lead to the Federalisation of Russia', RBC, 4 April, https://www.rbc.ru/opinions/ politics/04/04/2020/5e87291b9a7947054c55500f (accessed on 12 September 2020).

Leksin, I. 2016. 'Constitutional Federalism and Public Administration: Russia', in A. Farazmand (ed.), Global Encyclopaedia of Public Administration, Public Policy, and Governance. Cham: Springer International Publishing.

Leksin, I. 2018. 'The Dialectic between the BRICS Partnership and Multilevel Government in the Russian Federation', in Nico Steytler (ed.), The BRICS Partnership: Challenges and Prospects for Multilevel Government, pp. 20-31. Cape Town: Juta.

Leksin, I. and V. Seliverstov. 2017. Concurrency of Powers in the Russian Federation, in Nico Steytler (ed.), Concurrent Powers in Federal Systems: Meaning, Making, Managing, pp. 164-206. Leiden: Brill Nijhoff.

Leksin,V. 2008. Federativnaya Rossiya I ee regional'naya politika (Federal Russia and its Regional Policy). Moscow: INFRA. 
Mavrina, L. 2020. 'The Regions Used the Potential of Business Support to the Maximum', Vedomosti, 15 September, https://www.vedomosti.ru/economics/ articles/2020/09/14/839894-regioni-podderzhki (accessed on 15 October 2020).

National Rating Agency. 2020. 'Between Scylla and Charybdis: How Russian Regions Deal with Pandemic Economic Consequences', https://www.investinregions.ru/analytics/a/ materials-71332/ (accessed on 28 August 2020).

RBK Information Agency News. 2020. 2 April, https://www.rbc.ru/rbcfreenews/ 5 e85f9499a7947051649bb27 (accessed on 13 September 2020).

Seliverstov, V. E. 2015. 'Genesis of Federalism, Regional Development and Regional Policy of Post-Soviet Russia', in F. Palermo and E. Alber (eds), Federalism as Decision-making: Changes in Structures, Procedures and Policies, pp. 148-66. Leiden: Brill Nijhoff.

Smyth, R. et al. 2020. 'The Russian Power Vertical and the Covid-19 Challenge: The Trajectories of Regional Responses', PONARS Eurasia Policy Memos, 646, https:// www.ponarseurasia.org/memo/russian-power-vertical-covid-19-challenge-trajectoriesregional-responses (accessed on 18 September 2020).

St. Petersburg Policy Foundation. 2020. 'Rating', https://davydov.in/politics/rejtingfonda-peterburgskaya-politika-za-avgust-2020-goda/ (accessed on 23 September 2020).

TASS Information Agency News. 2020. 20 July, https://tass.ru/politika/9007027 (accessed on 13 September 2020).

Trunova, N. and D. Zemlyanski. 2020. "What Did the Sudden Onset of "Crisis" Federalism in Russia Lead to?', Forbes, 28 May, https://www.forbes.ru/finansy-iinvesticii/401625-k-chemu-privel-vnezapno-nastupivshiy-krizisnyy-federalizm-v-rossii (accessed on 28 August 2020). 